\title{
The University Internship Program and its Effects on Students' Employability Readiness
}

\section{Ismaela M. Bawica}

\begin{abstract}
Internships have traditionally been seen as a valuable way for university students to get preliminary job knowledge and experience, increasing their employability in a competitive labor market. The purpose of this study was to ascertain the internship program and its perceived effect on the employability readiness of selected graduating University students. Three individual factors (academic preparedness, positive attitude, and selfinitiative) and four organizational factors (challenging job, effective supervision, task clarity, and compensation) were identified as critical ingredients of a practical internship based on a literature review. To investigate this further, a quantitative study involving 88 student interns was conducted. The results showed that the internship was generally assessed as highly effective and has positive effects on the employability skills development and the attitude towards future career. The results of the study proved that the academic internship programs and internship placement access are both necessary structural elements of successful internship programs that result in positive experiences for students and employers. The results of this study can be an input to the University and partner organizations.
\end{abstract}

Keywords:

academic preparedness, positive attitude, self-initiative, task clarity, compensation

Suggested Citation: Bawica, I.M. (2021). The Effects of Internship Program on the Employability Readiness. International Journal of Academe and Industry Research, Volume 2, Issue 3, pp. 86-101.

\footnotetext{
About the author:

Instructor I, Laguna State Polytechnic University- San Pablo City, Philippines
} 


\section{Introduction}

The Commission on Higher Education (CHED) Memorandum Order 2017-104, Article III, defines internship as the practical application of classroom learning to the actual in a regular work environment. In Article I, Section 1, it states that the internship program is meant to provide students with an opportunity to complement their formal learning with practical knowledge, skills and desirable attitudes and to gain hands on experience in recognized Host Training Establishment (HTF). A college internship is a sort of experiential learning outside the classroom that serves as on-the-job training for various professions. These are typically temporary occupations that may be compensated or uncompensated, with or without college credit. Due to a lack of uniformity and control of internship programs across colleges and universities, the term "internship" remains subjective. While internships are typically reserved for college seniors as a capstone educational experience with an organization related to their major field of study, some students begin as early as their freshman or sophomore year to explore and determine their interest in a particular career, earn college credit, and connect with potential employers for paid permanent employment (Capek, Klein, \& Gassman, 2017; Cates-McIver, 1998; Getzel, Briel, \& Kregel, 2000; Giles \& Ryan, 2002). Employers profit as well from this relationship because experienced interns frequently require little or no training when they begin full-time employment. Over the last several decades, the critical nature of internships in finding full-time employment following graduation has become a reality and more of a requirement than an opportunity (Baert, et al., 2021; Haire \& Oloffson, 2009).

Internships are a popular method to combine classroom learning with real-world experience. These opportunities are meant to boost students' classroom learning as well as their job marketability after graduation. The internship procedure involves three parties: the university, the students, and the employers. However, the curriculum format differs between institutions and even within institutions. Thus, understanding the best structures for undergraduate student internship programs is crucial to their overall success. Student internship programs are offered as an academic component of learning by institutions of higher education as an efficient strategy to provide students with hands-on practical experience while also increasing their career marketability upon graduation.

Many schools and universities, as a best practice, give students the option of combining classroom learning with hands-on experiences in real-world scenarios. Classroom learning is articulated to accomplish overall academic program subject mastery, whereas outof-classroom learning reinforces and verifies the application of theoretical and pedagogical knowledge, intellectual and practical skills, and affective disposition (Kuh, 2000; Storey, 2010). Linking curricular (in-classroom) and co-curricular (out-of-classroom) internship programming is crucial to a student's preparation for educational and career goal achievement, as well as eventual post-graduation employability (Getzel, Briel, \& Kregel, 
2000; Williams, 2002). Higher education institutions are expected to develop and maintain a structure that exposes and assesses curricular and co-curricular activities, communicates such opportunities appropriately, and collaborates to institutionalize these activities for student success in their professional careers and lifelong learning.

Employability, as defined by Hillage and Pollard (1998) and Crossman and Clarke (2010), is the graduate's ability to obtain a job, maintain a job, or obtain a new job if necessary; being employable entails possessing the characteristics necessary to maintain employment and advance in the workplace, whereas being employed entails simply having a job. Thus, from an institutional standpoint, employability is about educating graduates with the capability and competence to obtain starting job. This requirement has ramifications throughout all aspects of university life, including academic programs and extracurricular activities. Employability training is critical for academic programs in terms of general education and discipline-specific information and skills necessary for future employment. To establish a good internship program, it is critical to consider the student's learning environment. Institutional administrators must commit to this process and persuade academicians to incorporate employability skills and traits into their teaching, not just in terms of what we teach, but also in terms of how we teach it. Curriculum creation for employability should begin with a curriculum plan that includes goals and learning outcomes statements. If the major does not require job experience, typical workplace duties should be established during the course of study. Academic preparation of interns enables them to apply theoretical knowledge, abilities, and essential concepts from their major or subject of interest in the workplace.

Collaboration between institutions and employers is beneficial for fostering workrelated learning and increasing interns' future employability. Employers and universities should agree on a standard set of skills and characteristics for interns. Institutions must be aware of what employers expect graduates to know, think, and do in order to adapt to workplace culture and be able to connect this to the educational process within the institution. Preparing students in this manner enables them to have a more realistic, productive, and fulfilling internship experience. This notion is reinforced by Institutional Theory (IT), which asserts that the institutional environment has a significant influence on the formation of formal structures within an organization, frequently more so than market pressures.

Through self-perception, this study aims to assess the students' view on the internship program and its effect on the employability readiness. The results serve as fundamental inputs to the institutional curriculum review and development as well as departmental program planning. These provide a link in the widening gap between the teaching and learning in higher education and the dynamic industry trends. 


\section{Literature Review}

\subsection{The Early Practice of Internship}

Numerous experts concur that an internship is an essential component of job growth (Spradlin, 2009). Internships evolved from professional apprenticeships that began in the 11th and 12th centuries with The Trade Guilds of Europe. Master craftsmen and tradesmen took on young apprentices who worked for them for the majority of their adolescent years before graduating as journeymen and earning a living wage. Frequently, apprentices chose to continue working with the masters who trained them. Eventually, the guild system succumbed to industrialization and the expansion of formal professional education (Sides \& Mrvica, 2007). Reginald Bray's 1911 book, Boy Labor and Apprenticeship, discusses the apprenticeship's primary purposes, which included monitoring, training, and filling job gaps. While these objectives are comparable to those of contemporary internship programs, the framework of apprenticeships was more defined than that of contemporary internships.

Today's internship program has little resemblance to the Middle Ages' apprenticeship program, despite the fact that both aim to cultivate potential new workers for entry into the labor force (Haire \& Oloffson, 2009). According to the English trade guilds, a worker would pay to learn from a master trainer who could teach in any field of skilled labor in the 11th century. This instruction may span several years and may begin as early as age 16, and the apprentice may rely on the master for food, clothes, and shelter in many circumstances. In the 18th century, with the advent of the Industrial Revolution, this practice gradually ceased, and a new tendency toward universal factory employment necessitated the establishment of vocational schools (Haire \& Oloffson, 2009). Apprenticeships revived in certain areas during the twentieth century, governed by trade unions and legislation. The National Apprenticeship Act of 1937 resulted in the founding of the Bureau of Apprenticeship and Training under the United States Department of Labor, which collaborates with employers, labor organizations, and educational institutions to promote apprenticeship programs (Haire \& Oloffson, 2009).

Following World War I, a medical school was no longer considered adequate preparation for practice. As a result, the word "intern" was coined to refer to a person in the medical profession who is currently pursuing a degree but does not yet possess a license to practice (Haire \& Oloffson, 2009). Later on, the term was used in politics to refer to persons interested in learning about careers in government, in place of the term apprentice.

Meanwhile, cooperative education initiatives developed in colleges and universities. These programs allowed students to work for an extended length of time at a corporation while studying college. In the $1980 \mathrm{~s}$, when the average private college tuition hit approximately $\$ 9,000$, co-ops provided students with an opportunity to earn money while receiving hands-on experience (Haire \& Oloffson, 2009). Between 1970 and 1983, the number of postsecondary institutions offering cooperative education expanded by more than 
tenfold, from 200 to 1,000. (Haire \& Oloffson, 2009). In the United States, the University of Cincinnati was the first postsecondary institution to offer cooperative education in 1906, followed by more than a dozen others within two decades, including Northeastern University (1909), Kettering University (1909), University of Pittsburgh (1910), University of Detroit (1911), Georgia Institute of Technology and Rochester Institute of Technology (1912). (Cerdercreutz \& Cates, 2010; Weible, 2009). Co-op programs were originally created to allow students to work in a firm for a specified period of time throughout the school year, allowing them to explore careers while earning money to cover their tuition (Haire \& Oloffson, 2009). The program required an additional year to get a bachelor's degree. Cooperative education did not gain popularity until the 1960s. Similarly to co-op, internship programs did not begin until the 1960s and were initially uncommon. Initially, internship programs were marketed as a way for students to stay connected to their academic program while exploring career choices (Haire \& Oloffson, 2009). While the internship has become the de facto standard for students seeking important on-the-job experience prior to receiving their diplomas, today's internships are a long cry from their forerunners.

\subsection{The Value of University Internship Programs}

Internships provide a platform for academic students to blend theoretical knowledge with real-world working situations and put it into practice (Sahrir, et al., 2016). Students can put what they've learned in class to use in real-world circumstances thanks to internship programs. As a result, individuals must participate in well-planned and supervised programs that address their future goals (Muhamad et al., 2009; Alexei et. al., 2013). By having such internship programs, students will get practical skills that will improve their grasp of issues relevant to a specific job (Hughes, 1998; Furco, 1996) and increase their readiness in employability.

Researchers across the world have conducted research in various aspects of internship programs in various disciplines of study. Alpert, Heaney, and Kuhn (2009) conducted a study on the goals, structure, and assessment of undergraduate marketing internships in Australia. Batool, Ellahi, and Masood (2012) conducted a study in Pakistan's Punjab province on the consequences of the National Internship Program (NIP) for graduates from 2006 to 2010. Katyal and Arora (2013) conducted a study in the same region of Punjab to examine graduate employability and students' labor market orientation. Phoebe (2010) did a study on the variables of internship effectiveness for university students in Hong Kong. Chen, Hu, Wang, and Chen (2011) conducted a study in Taiwan on the effect of internship experience on the behavioral intentions of college students majoring in leisure management. Bukaliya (2012) did a study on the issues of internship in Open and Distance Learning (ODL) programs in Zimbabwe. All these studies highlighted the positive effects of university internship programs to the employability readiness of students from various disciplines. 
According to Phoebe (2010), internship is an effective mechanism for developing university students' preliminary job knowledge and experience in order to increase their employability in a competitive labor market. This study examined the factors of internship success in order to assist colleges in improving their placement programs in order to increase graduates' employability. It investigated and assessed three individual and four organizational elements that influence internship effectiveness, as well as the amount to which student intern traits and company policies affect intern success. It was concluded that the four organizational (employer) factors of job challenge, effective supervision, task clarity, and compensation were all significantly associated with the effectiveness of the internship program, and that the three individual factors of self-initiative, academic preparedness, and positive attitude of the intern were all significantly associated with success.

In 2010, NACE surveyed businesses and educators to determine how frequently approved experiences such as internships were evaluated. The study's objective was to discover whether the educational value of the identified internship experience was the most essential aspect, as well as the effect of money on such internships. NACE found that career services professionals and businesses may collaborate to ensure that any experiential learning fulfills and conforms to a set of established standards that allows it to be regarded a valid internship and offered ethically to students.

In their review of the benefits of internships at business colleges, Knouse and Fontenot (2008) identified several benefits for students who choose to participate in internships: students increase their chances of finding work, may receive an offer for a fulltime job position from the companies that hired them as interns, and acquire experiences that may motivate them to choose a particular car. According to the aforementioned findings, a recent review by Sanahuja Vélez and Ribes Giner (2015) identified three distinct types of benefits for graduates: "(a) those related to the enhancement of employment opportunities, (b) those related to the development of skills and competencies, and (c) those related to the effects on career exploration" (p. 123). Similarly, multiple studies indicate that students are increasingly viewing internships as a practical tool that will pave the way to work (Cannon and Arnold, 1998). Young graduates who participate in internship programs are more likely to be offered a continuation of their employment with the internship provider company (Zhao and Liden, 2011), earn on average more money and receive more job offers (Callanan and Benzing, 2004; Coco, 2000; Gault et al., 2000), land their first job more quickly (Gault et al., 2000; Knouse et al., 1999), and improve their future prospects (Gault et al., 2000). (Chen et al., 2011). It is not uncommon for recent graduates to struggle under the pressure of workrelated issues (Wang, 2002). Prior to the interview, university graduates who participated in internship programs appear to be more potential job candidates than those who did not complete internship (Divine et al., 2007).

Negotiating acceptable and meaningful projects to be completed during the internship period might be difficult. By definition, each project is unique, and the amount of work 
required to accomplish the desired result may be difficult to estimate and vary from project to project; boundaries must be clearly specified (Weisz and Smith, 2005). Finding the correct balance will require skilled university staff facilitation. Creating an optimal learning environment for internships can be challenging and complex, as, unlike in the classroom, the student is not always the primary focus of attention, and learning experiences are frequently unique and unanticipated (Billett, 2006). As a result, establishing a tightly defined program of workplace learning is challenging (Flinders University, 2009). Employers, too, must grasp the student's educational expectations, and the university's role in the learning experience.

\section{Methodology}

This is a descriptive study. It is a fact-finding investigation that includes proper and accurate interpretation. This method was used to determine the influence of an internship program on the employability readiness of university students.

The 100 graduating students at Laguna State Polytechnic University were study participants however only 88 accomplished survey questionnaires were retrieved. This gives a retrieval rate of $88 \%$. The participants of the study are mostly female $(55.68 \%)$ and taking education, computer science, arts, business administration, accountancy, engineering and hospitality management and tourism programs with Cumulative Grade Point Average of 1.00 to $1.25(42.05 \%)$. As to the industry placement, students were mostly interns in business service, engineering and hospitality management tourism $(25 \%)$ and schools and financial institutions $(12.5 \%)$.

The main tool for data gathering was a self-structured questionnaire. It is divided into three parts: 1) profile of the respondents; 2) assessment of the internship practices and 3) assessment of lessons learned during the internship.

When the approval was granted by the College Dean and Campus Director, the distribution of questionnaires started. The students were approached during their classes for easy facilitation. The completed questionnaires were retrieved afterwards.

Frequency, weighted mean and standard deviation were the statistical analysis used.

\section{Findings and Discussion}

Table 1 shows the university students' assessment of their internship practices and perceptions. The perception on internship was grouped into the students' individual attitudes and initiatives toward their job and the organizational supervision given during the internship. The internship was generally assessed as highly effective as show by the students' strong agreement on the various indicators with the overall mean of 4.57 . 
The highest mean of 4.94 was given to the supervisors' feedback about the interns' performance. The importance of feedback in order to improve job performance was highlighted in the assessment. In terms of the interns' attitude and initiatives, their initiative to volunteer for the tasks was highlighted with a mean of 4.77. Being able to volunteer for the tasks signify the students' ability to excel and prove their worth in the workplace. Although students rated all the indicators with strongly agree, the lowest mean of 4.33 was given to the advice given by their supervisor to improve their performance. It is ironic that supervisors give feedback but not consistent on the advice to improve the performance.

Table 1

Students' Perception on Internship

\begin{tabular}{|c|c|c|c|}
\hline Indicators & Mean & SD & VI \\
\hline \multicolumn{4}{|l|}{ Individual Attitude and initiatives } \\
\hline a) My college courses gave me the skills needed to perform well on the job. & 4.55 & 0.1495 & SA \\
\hline b) I treated it like a real job. & 4.55 & 0.1495 & SA \\
\hline c) I treated it like a potential learning opportunity. & 4.65 & 0.1505 & SA \\
\hline d) I knew the good points and bad points of the job when I was hired. & 4.45 & 0.1525 & SA \\
\hline e) I often volunteered for tasks. & 4.77 & 0.1567 & SA \\
\hline f) I proactively asked questions. & 4.42 & 0.1541 & SA \\
\hline g) I proactively got acquainted with other employees. & 4.5 & 0.1505 & SA \\
\hline h) I proactively asked for feedback during internship. & 4.43 & 0.1535 & SA \\
\hline i) I was required to use a number of complex or high level skills. & 4.65 & 0.1505 & SA \\
\hline j) The job was quite simple and repetitive. & 4.49 & 0.1508 & SA \\
\hline \multicolumn{4}{|l|}{ Organizational Supervision } \\
\hline $\begin{array}{l}\text { k) My supervisor considered my interests and goals and adapted the internship } \\
\text { accordingly. }\end{array}$ & 4.73 & 0.1541 & SA \\
\hline $\begin{array}{l}\text { 1) My supervisor provided assignments that gave me the opportunity to develop } \\
\text { and strengthen new skills. }\end{array}$ & 4.55 & 0.1495 & SA \\
\hline m) My supervisor gave me helpful feedback about my performance. & 4.94 & 0.1543 & SA \\
\hline $\begin{array}{l}\text { n) My supervisor gave me helpful advice about improving my performance when I } \\
\text { need it. }\end{array}$ & 4.33 & 0.1737 & SA \\
\hline o) I was given a clear plan about what assignments I have to do. & 4.51 & 0.1608 & SA \\
\hline p) I was given a clear plan about how to do the assignments. & 4.68 & 0.1543 & SA \\
\hline Over-all & 4.57 & & SA \\
\hline
\end{tabular}

Legend: 4.5-5.0 = Strongly Agree (SA); 3.5-4.5 =Agree (A); 2.5-3.4 =Undecided (U); 1.5-2.4 =Disagree (D); 1.0$1.4=$ Strongly Disagree $(S D)$

An internship experience is a vital component of student learning for college students since it enables them to augment their academic studies with practical experience in educationally favorable environments (NACE, 2011). As a result, personal characteristics, 
and a willingness to learn are critical for acquiring knowledge and developing skills. As Verney, Holoviak, and Winter (2009) stress that employer evaluations of student interns during the internship can be an effective technique of monitoring student learning and reviewing and amending program quality. This indicates that institutions that offer a welldesigned and managed internship program not only position their students upon graduation, but also validate their curriculum in real-world contexts. If employers are content with their interns, it is presumed that the university's curriculum fulfills or surpasses the standards of the employers. Thus, employer evaluation of the intern is critical for determining the program's overall efficacy.

Because internship programs require the integration of the goals and expectations of three parties the institution awarding the internship, the student seeking the internship, and the employer providing the practical training maximizing the student experience can become challenging, even more so when assessing the program's activities, outcomes, and overall success. Several of these obstacles can be overcome by establishing standards and rules that promote consistency in practice (Kelley, 2004; Young \& Baker, 2004). To apply information constructively in field-based settings, all students should encounter in-depth questioning from faculty, staff, and other mentors regarding their assumptions, analyses, findings, and actions. Learners also need both supervision and feedback, from mentors and peers, as they examine the facets of a complicated subject and evaluate their own discoveries against both theory and the experiences of others (AAC\&U, 2007).

What differentiates internships from other forms of active learning is the degree of supervision and self-study that enables students to "learn by doing" and reflect on their learning in ways that support specific learning goals and objectives. It is critical to receive feedback for improvement and to build or refine learning objectives. What differentiates an intern from a volunteer is the deliberate manner in which learning occurs. In order to succeed, there must be a balance between studying and contributing, and the student must contribute in some way must take responsibility for both his or her institution and the internship placement site all share responsibility for ensuring the balance is proper and that the learning is valuable to justify the effort, which may include academic credit. 
Table 2

Students' Perception on Effects of Internship

\begin{tabular}{|l|c|c|c|}
\hline \multicolumn{1}{|c|}{ Indicators } & \multicolumn{2}{c|}{ Smployability Skills Development } & Mean \\
\hline \multicolumn{1}{|c|}{ SD } \\
\hline a) Analytical skills & 4.48 & 0.1159 & SA \\
\hline b) Computer applications & 4.51 & 0.1156 & SA \\
\hline c) Creative thinking & 4.6 & 0.1172 & SA \\
\hline d) Information search & 4.41 & 0.1186 & SA \\
\hline e) Problem solving & 4.74 & 0.1273 & SA \\
\hline f) Oral communication & 4.41 & 0.1186 & SA \\
\hline g) Written communication & 4.4 & 0.1192 & SA \\
\hline h) Proposal writing & 4.45 & 0.1168 & SA \\
\hline i) Leadership skills & 4.58 & 0.1165 & SA \\
\hline j) Teamwork & 4.4 & 0.1192 & SA \\
\hline k) Relationship building & 4.72 & 0.1253 & SA \\
\hline \multicolumn{1}{|c|}{ Attitude towards future career } & \multicolumn{2}{|c|}{} \\
\hline l) I know what kind of job fits me. & 4.5 & 0.1253 & SA \\
\hline m) I just can't make up my mind what type of work I am suitable for. & 4.72 & 0.1156 & SA \\
\hline n) I know my values well enough to make a career decision right now. & 4.5 & 0.1192 & SA \\
\hline o) I have a real clear picture of what kind of person I am. & 4.4 & 0.1156 & SA \\
\hline p) I just don't know if I have the traits that some kinds of work require. & 4.5 & 0.1253 & SA \\
\hline & 4.52 & SA \\
\hline
\end{tabular}

Legend: 4.5-5.0 = Strongly Agree (SA); 3.5-4.5 =Agree $(A) ; 2.5-3.4$ =Undecided $(U) ; 1.5-2.4=$ Disagree $(D) ; 1.0$ $1.4=$ Strongly Disagree $(S D)$

Table 2 shows the students' self-assessment on the effects of the internship on the employability skills development and the attitude towards future career. The overall assessment of 4.52 or Strongly Agree reflects the positive effects of the internship on the employability skills development and the attitude towards future career. In terms of the employability skills, the highest rated was problem solving with 4.74 weighted mean. The internship helps enhance the problem solving abilities of the students that aid in their effective decisions. Meanwhile, the attitude towards their future career shows that students are still not decided on the type of career suitable for them with a weighted mean of 4.74. Although the indicators are all rated with 'strongly agree', the lowest mean of 4.40 was given to the value of teamwork as employability skill. The lower placement of teamwork implies two possible scenarios about the nature of job. The students must not have been given tasks with a team or there are less personnel in the department.

It is always said that hiring managers spend fewer than ten seconds per resume. Within that brief period, managers are on the lookout for specific must-have skills that appear often in employment and internship ads. This is because businesses are aware of the skills they seek in new college hires and hence hunt for specific vital competencies. According to NACE's Job Outlook 2019 poll, critical thinking/problem solving is one of the top four abilities companies look for in new college recruits. Teamwork/collaboration, 
professionalism/work ethic, and oral/written communication are the other three (Guterman, 2020)

Businesses face complicated new challenges on a daily basis in today's fast-paced environment. Additionally, there is a wealth of information available to everyone-not all of it reliable. Interns and employees who are capable of independently resolving challenges make life easier for their superiors and coworkers. When necessary, the majority of people are capable of making a choice. However, when someone thinks critically about a situation and goes through it step by step, they are more likely to choose the right choice. That is because they inquire, examine evidence, critically analyze their own prejudices, and consult with others. When all of this is considered, it becomes clear that a person with good critical thinking skills is considerably more likely to take effective action that results in a successful outcome. And this is beneficial to the firm and its bottom line.

Additionally, critical thinkers and problem solvers are generally inspirational and pleasurable to work with. Because they evaluate their own biases and consider opposing viewpoints, they are typically receptive, respectful, and rational. These abilities are especially critical for college hires. Interns and entry-level employees that can think critically and solve problems require less supervision and can provide new perspectives and ideas. At the same time they are adaptable and receptive.

While obtaining job experience, the internship enables students to develop their generic and specific abilities. Numerous categorizations exist in the literature for work skills or employability abilities. O'Neil (1997) divides them into four categories: fundamental academic abilities (listening and speaking); higher-order cognitive abilities (reasoning, problem solving, and creativity); interpersonal and teamwork abilities; and personal qualities and attitudes (self-esteem, motivation and responsibility). Gault et al. (2000) conducted a review of the literature to determine the most important skills for hiring criteria used to select new graduates: communications skills (oral presentations, proposal writing, and written communication), academic skills (analytical skills, computer applications, creative thinking, information search, and problem solving), leadership skills (leadership/teamwork, and relationship building), and jovial skills. Recent research by Chhinzer and Russo (2018) on the talents required by hiring businesses demonstrate that "generic skills (time management, teamwork, attention to detail), general mental capacity, subject-specific knowledge, willingness to work, and attitudes and while some studies emphasize the value of soft skills over academic credentials, e.g. academic repute, other research emphasize the relevance of soft skills over academic credentials (Finch et al., 2013)

\section{Conclusion}

This descriptive study evaluated the effects of internship program to the employability readiness of the 88 intern students at a public university in San Pablo City in 
the Philippines. The self-structured questionnaire assessed the self-perception of the predictors and criterions of internship. Frequency, weighted mean and standard deviation were the statistical analysis used.

The results showed that the internship was generally assessed as highly effective as show by the students' strong agreement on the various indicators with the overall mean of 4.57. Similarly, the students' self-assessment on the effects of the internship on the employability skills development and the attitude towards future career showed an overall assessment of 4.52 or Strongly Agree that reflects the positive effects of the internship on the employability skills development and the attitude towards future career. It was further revealed that the supervisors' feedback about the interns' performance was valuable for the students. The students also showed strong initiatives as their initiative to volunteer for the tasks was highlighted with a mean of 4.77. In terms of the employability skills, the highest rated was problem solving with 4.74 weighted mean. However, the attitude towards their future career shows that students are still not decided on the type of career suitable for them with a weighted mean of 4.74 .

The results of the study proved that the academic internship programs and internship placement access are both necessary structural elements of successful internship programs that result in positive experiences for students and employers. While it is typical for students to do internships without the backing of an academic, for-credit program, internships are considered a collaborative effort between academic institutions, companies, and students as a best practice. Each has its own aims, and the form of the partnership has a significant impact on how each purpose is reached or not.

The results of this study can be an input to the University and partner organizations. These are fundamental to the curriculum review and development. The assessments could highlight the necessary improvements on the internship program, co-curricular and extracurricular activities necessary for the employability skills development.

The current study has various statistical, sampling and questionnaire limitations. Further studies are highly recommended to strengthen and validate the results presented herein. Other researchers could consider other variables and develop a more comprehensive questionnaire to completely assess the internship programs.

\section{References}

Adi, I Gede Purnawan; I Wayan Bagia, dan Wayan Cipta. (2016). "Pengaruh Promosi Jabatandan Disiplin Kerja terhadap Kinerja Pegawai”. e-Journal Bisma Universitas PendidikanGanesha. Vol.4. 
Ahmed, A. (2019). The Importance of a Good Attitude on the Job. Retrieved on July 4, 2021, from https://bizfluent.com/about-7277260-importance-good-attitudejob.html

Alpert, F., Heaney, J. G., \& Kuhn, K. A. L. (2009). Internships in marketing: Goals, structures and assessment-student, company and academic perspectives. Australasian Marketing Journal, 17(1), 36-45.

Andrews, J. and Higson, H. (2008), “Graduate employability, 'soft skills'versus 'hard'business knowledge: a European study",Higher Education in Europe, Vol. 33 No. 4, pp. 411-422.

Association of American Colleges and Universities. 2007. College Learning for the New Global Century: A Report from the National Leadership Council for Liberal Education and America's Promise. Washington, DC: Association of American Colleges and Universities.

Baert, S., Neyt, B., Siedler, T., Tobback, I. \& Verhaest, D. (2021). Student internships and employment opportunities after graduation: A field experiment. Economics of Education Review, Volume 83, August 2021, 102141

Batool, Z., Ellahi, N., \& Masood, A. (2012). National internship programme and its evaluation: A case study of Punjab region. Academic Research International, 2(2), 562-570.

Bay, J. (2006). Preparing undergraduates for careers: An argument for the internship Practicum. College English, 69(2), 134-141.

Beard, C. and Wilson, J.P. (2013), Experiential Learning: A Handbook for Education, Training and Coaching, 3rd ed., Kogan Page, Philadelphia, PA.

Bukaliya, R. (2012). The potential benefits and challenges of intership programmes in an ODL institution: A case for the the Zimbabwe open university. International Journal on New Trends in Education, 3(1), 118-133.

Callanan,G. \&Benzing,C. (2004). Assessing the role of internships in the career-oriented employment of graduating college students. Education \& Training, 46(2), 82-89. Retrieved November 9, 2009, from ABI/INFORM Global. (Document ID: 1367700271).

Capek, Megan; Klein, Jonathan; and Gassman, Julianne (2017) "Paid versus Unpaid Internships: Perspectives of Students and Nonprofit Directors," The International Undergraduate Journal For Service-Learning, Leadership, and Social Change: Vol. 7: Iss. 1, p. 11-20

Chegg Company. (2013). Bridge that gap: Analyzing the student skill index. Retrieved from https://www.insidehighered.com/sites/default/server_files/files/Bridge\% 20That\%20Gap-v8.pdf 
Chen, C.F. (2011), "A study of the effects of internship experiences on the behavioural intentions of college students majoring in leisure management in Taiwan", Journal of Hospitality Leisure Sport \& Tourism Education, Vol. 10 No. 2, pp. 61-73.

Chhinzer, N. and Russo, A.M. (2018), "An exploration of employer perceptions of graduate student employability", Education +Training, Vol. 60 No. 1, pp. 104-120.

Cho, M. (2006), "Student perspectives on the quality of hotel management internships" ,Journal of Teaching in Travel \& Tourism, Vol. 6 No. 1, pp. 61-76.

Cook, S. J., Parker, S. R., \& Pettijohn, C. E. (2004). The perceptions of interns: A longitudinal case study. Journal of Education for Business, 79, 179-185.

Council for the Advancement of Standards in Higher Education (CAS). (2006). CAS professional standards for higher education (6th ed.). CAS standards contextual statement. Washington, DC: Author.

Council for the Advancement of Standards in Higher Education (CAS). (2009). CAS Professional Standards For Higher Education (7th ed.). Washington, DC: Author.

Crossman, J. E., \& Clarke, M. (2010). International experience and graduate employability: Stakeholder perceptions on the connection. Higher Education, 59, 599-613.

Delaware Valley College. (2014). Employers' guide to student professional-educational experiences. The Center for Student Professional Development. Retrieved from http://www.delval.edu/pdf/2014-E360-Employer-Guide.pdf

Dixon, M. A., Cunningham, G. B., Sagas, M., Turner, B. A., \& Kent, A. (2005). Challenge is key: An investigation of affective organizational commitment in undergraduate interns.

Engstrom, C. M., \& Tinto, V. (2000). Developing partnerships with academic affairs to enhance student learning. In M. J. Barr, \& M. K. Desler (Eds.). The handbook of student affairs administration (2nd ed., pp. 425-452). San Francisco, CA: Jossey Bass Publishers.

Eyler, J. (2009). Effective practice and experiential education. Paper presented at the National Conference on Liberal Education and Effective Practice, Worcester, MA.

Garver, M., Spralls, S. A. III, \& Divine, R. L. (2009). Need-based segmentation analysis of university career services: Implications for increasing student participation. Research in Higher Education Journal, 3, 1-27.

Gault, J., Leach, E. and Duey, M. (2010), "Effects of business internships on job marketability: the employers'perspective" ,Education +Training, Vol. 52 No. 1, pp. 76-88. 
Gichure, C. (2014). Factors Influencing Employee Motivation and Its Impact on Employee Performance: A Case of Amref Health Africa in Kenya. A Research Project Report Submitted to Chandaria School of Business

Gupta, C. B. (2011). Human Resource Management. New Delhi: Sultan Chand \& Sons

Haire, M., \& Oloffson, K. (2009, July). Interns (brief history). Retrieved from http:// www.time.com/time/nation/article/0,8599,1913474,00.html

Heart Research Associates. (2013). It takes more than a major: Employer priorities for college learning and student success. Washington, DC: The Association of American Colleges and Universities. Furco, A. (2009). Effective methods for assessing the impact of service-learning on students, institutions, and communities. Minneapolis: University of Minnesota.

Howard, A. (2004). Cooperative education and internships at the threshold of the twentyfirst century. In P. L. Linn, A. Howard, \& E. Miller, Handbook for research in cooperative education and internships (pp. 3-10). Mahwah, NJ: Lawrence Erlbaum.

Huhman, H. R. (2013). The evolution of the internship [infographic]. Retrieved from http://theundercoverrecruiter.com/internship-evolution/

In a New Generation of College Students, Many Opt for the Life Examined." New York Times, April 6, 2008 www.nytimes.com/2008/04/06/education/06philosophy.html.

Jackel, D. (2011). Evaluating the Effectiveness of an Internship Program.

Job Outlook. (2003). Employer survey. Bethlehem, PA: National Association of Colleges and Employers.

Kuh, George D. 2008. High-Impact Educational Practices: What They Are, Who Has Access to Them, and Why They Matter. Washington, DC: Association of American Colleges and Universities

Narayanan, V.K., Olk, P.M. and Fukami, C.V. (2010), "Determinants of internship effectiveness: an exploratory model", Academy of Management Learning \& Education, Vol. 9 No. 1, pp. 61-80.

O’Neill, N. (2010). Internships as a high-impact practice: Some reflections on quality. Peer Review, 12(4), 4-8.

Phoebe, W. K. (2010, April 29). Determinants of internship effectiveness for university students in Hong Kong (unpublished doctoral dissertation). Hong Kong Baptist University, China.

Radigan, J. (2009). The role of internships in higher education. Retrieved from http://www.asee.org 
Reardon, R., Lenz, J., \& Folsom, B. (1998). Employer ratings of student participation in non-classroom-based activities: Findings from a campus survey. Journal of Career Planning \& Employment, 58(4), 36-39.

Sides, C. H., \& Mrvica, A. (2007). Internships: Theory and practice. Amityville, NY: Baywood.

Storey, K. L. (2010). Bridging the gap: Linking co-curricular activities to student learning outcomes in community college students (Doctoral dissertation). Retrieved from http://digitalcommons.nl.org. 